\title{
SIGHT RECORD OF GREEN HERON AT DELTA, MANITOBA
}

by Roger M. Evans, Zoology Department, University of Manitoba and Robert W. Nero, Manitoba Museum of Man and Nature, Winnipeg

A bird with characteristics similar to those of an adult Green Heron (Butorides virescens) was observed and identified by Dr. C. H. S. Watts and $\mathrm{Mr}$. D. Krindle on June 5, 1967, at the University of Manitoba Field Station located at Delta, Manitoba. The following day a bird of similar size and proportions was observed by Mr. Krindle along with Martin McNicholl and the senior author, but conditions did not permit definite identification at that time. A more positive identification was obtained on June 7 , when the same spot was again visited by the senior author. On this latter date, a bird subsequently identified as a Green Heron was flushed at close range, along with three Blackcrowned Night Herons. The Green Heron and one of the Night Herons perched near the tops of oak trees, some 50 yards from each other and approximately 100 yards from the observer. When the perched birds were viewed at this range through $7 \times 50$ binoculars, the Green Heron appeared to be noticeably smaller than the Night Heron. Additional visible features characteristic of an adult Green Heron included yellow legs, reddishchestnut neck with light-colored strip extending down along the front, and dark brown or black crest feathers. Although the same spot was visited frequently over the next two weeks, no further sightings were made. Two Green Herons were never seen simultaneously, and there was no evidence that this species was nesting in the area.

A possible sighting of a Green Heron at Saskatoon, Saskatchewan on June 22, 1966 (Matthews, 1967) is apparently the only other report of this species for western Canada.

Thompson (otherwise, E. T. Seton) $(1891: 490)$, refers to a report of this species in Manitoba by J. Macoun for
1881, and records by Hunter, who had reportedly "taken them at Shoal Lake, near Winnipeg, and am told that they breed in the sloughs around Turtle Mountains . . ." However, Macoun later says (in Macoun and Macoun, 1909:143) that probably both he and Hunter were mistaken, and that these were likely Blackcrowned Night Herons, a species not reported by either of them.

An old report by Seton of a sight record of a Green Heron at Brandon has been cited by the A.O.U. Checklist (1957) and recently was used by Godfrey (1966:38). Godfrey has since stated (pers. corres., R. W. Nero, April 14, 1967): “ . . . the evidence is not very good and I now wish I had not included it ... it was a sight record and therefore, by implication, hypothetical." The Seton records (1908:2) for Brandon were as follows: "W. Shaw Cottingham reports having seen a Green Heron at Brandon. C. C. Helliwell, another (not seen by me)."

In the absence of further details, these earlier data must be considered insufficient evidence for the occurrence of this species. Hence, the present record is regarded as the first valid report for this province. In the absence of a specimen or photograph, this species is now considered hypothetical for Manitoba.

\section{LITERATURE CITED}

American Ornithologists' Union Committee. 1957. Check-list of North American birds. 5 th edition. Baltimore. $691 \mathrm{pp}$.

Godfrey, W. E. 1966. The Birds of Canada. Natl. Mus. Can. Bull. No. 203, Biol. Series No. 73. Ottawa. 428 pp., 69 color plates, 71 line drawings, 2 maps.

Macoun, J., and J. M. Macoun. 1909. Catalogue of Canadian birds. Can. Dept. Mines. Geol. Surv. Branch, Ottawa. 761 pp.

Matthews, C. A. 1967. Possible sighting of a Green Heron. Blue Jay, $25: 24$.

Seton, E. T. 1908. Recent bird records for Manitoba. Auk, 25:450-453.

Thompson, E. E. 1891. The birds of Manitoba. Proc. U.S. Natl. Mus., Vol. 13, 1890. pp. 457-643, Washington. 